\title{
Beti Bachao Beti Padhao Program to Save the Girl Child-Educated the Girl Child: Impact Analysis of Government of India Flagship Program in Uttar Pradesh, India
}

\author{
Vipul Vaibhav Pandey*1, Ajay Kumar Singh ${ }^{2}$ and Upadhaya SK ${ }^{3}$ \\ ${ }^{1}$ International Institute for Population Sciences, Mumbai, India \\ ${ }_{2}^{2}$ Joint Director, State Council of Education Research and Training (SCERT), India \\ ${ }^{3}$ Consultant SCERT, India
}

Received: 鴊: October 05, 2018; Published: 制: October 31, 2018

*Corresponding author: Vipul Vaibhav Pandey, International Institute for Population Sciences, Mumbai, India

\section{Research Document}

Complete enumeration of Population in terms of gender composition is a key indicator to scrutinize the tempo of development of a country. Examining the overall sex ratio, the number of females per 1,000 males, is falling across the world. While the global sex ratio was 986 females per 1,000 males in 2010, it reduced to 984 in 2011. As per nature's own balance, 940-950 girls are born per 1000 boys. By finding out the number of girls actually born per 1000 boys, we can calculate the Sex Ratio at Birth (SRB). Similarly, by finding out the number of girls per 1000 boys in the 0-6 years age group, we get to know the Child Sex Ratio (CSR). India's child sex ratio dipped tremendously i.e. 62 points (976 to 914) from 1961-2011, worst since the country's independence. The 2001 census provides CSR data at the national, state and district levels. The Sample Registration System (SRS) also provides data on SRB at the national and state levels. Demographically the ratio has increased from 927 females per 1000 males to 940 from census of 1991 to 2011; however, this ratio is alarmingly decreasing among children in the age group of 0-6 and the as per the 2011 census there are 914 females for 1000 males. If it continues, it's going to further deepen the gender imbalance in the society. The largest populated sate in India Uttar Pradesh, child sex ratio has also dip from 850 in Census 2001 to 841 in census 2011. SRB provides a more accurate indication of the extent to which sex selection occurs in a community.

The prevailing patriarchal society creates a gender imbalance by viewing the male as an asset and female as a liability. Government of Uttar Pradesh is making every effort to improve the child sex ratio by giving various incentives to parents with female child. Various women welfare schemes are being implemented and many others are in the pipeline. Sex ratio imbalance and sex selective abortion brought spotlight among researchers, academicians and programmers in last two decades, but the situation by and large is still in favour male child. To explicate the issue incessant and ceaseless efforts is necessary to study the divergence and varying pattern of child sex ratio and to inform policy makers and planners to achieve desired balance in sex ratio. Using Census 2011 and across all 10 districts in Uttar Pradesh and through latest round of UDISE data; this advocacy document paper examines the determinants of declining child sex ratio and the situation and pattern of District profiles in Uttar Pradesh. Analysing the Census data, the results clearly brings out one pin-point fact that Sex Ratio at Birth (SRB) remains favorable to male child in recent census for all the selected BBBP districts establishing son preference and sex selective abortion (Table 1).

The socio-cultural practices in Uttar Pradesh are pre-dominantly favouring the males mostly due to the patriarchal structure of the society. Indian culture, tradition and family beliefs are mostly advantageous to male and male child are treated as asset leading to discrimination against girl child and in worst case scenario, female feticides (aborting female babies) resulting in skewed sex ratio. The foremost cause for abortions are structural imbalance in the society, Financial (Property, Dowry, Marriage, culture) and 
various religious and spiritual myths. Girls are viewed as a burden, various beliefs and social factors have resulted in widespread discrimination against the girl child resulting in alarming decrease in child-sex ratio in the state of late, particularly so in some districts, and this is where the roots of Female Feticides in Uttar Pradesh lies.

Table 1: List of 100 low CSR (child Sex ratio) districts covering all states \& UTs.

\begin{tabular}{|c|c|c|c|}
\hline S.No & Districts & CSR Census 2001 & CSR Census 2011 \\
\hline 1 & Baghpat & 850 & 841 \\
\hline 2 & Gautam Buddha Nagar & 854 & 843 \\
\hline 3 & Ghaziabad & 854 & 850 \\
\hline 4 & Meerut & 857 & 852 \\
\hline 5 & Bulandshahr & 867 & 854 \\
\hline 6 & Agra & 866 & 861 \\
\hline 7 & Muzaffarnagar & 859 & 863 \\
\hline 8 & Mahamaya Nagar & 886 & 865 \\
\hline 9 & Jhansi & 886 & 866 \\
\hline 10 & Mathura & 872 & 870 \\
\hline
\end{tabular}

Sex selection has occurred, since it takes place behind closed doors, with connivance between the medical service provider and parents. The Pre-conception and Pre-natal Diagnostic Techniques Act (PCPNDT Act) prohibits sex selection, before or after conception, for the prevention of their misuse for sex determination leading to female foeticide; and, for matters connected therewith or incidental. The law suffers from the bottlenecks of implementation, and there have been few convictions so far. The major difficulty relates to proving that an offence it was assumed it might improve the situation however this did not happen. Although there has been ample time for implementing the Act, there is no sign that the decline in child sex ratio has been improved

\section{Beti Bachao Initiative in Uttar Pradesh}

After the successful implementation of government schemes like Sarva Siksha Abhiyan (SSA), Swachh Bharat Abhiyan, government launched another flagship program 'Beti Bachao, Beti Padhao' (save the girl child, educate the girl child), on January 22, 2015 in Panipat, Haryana. Later on, it was expanded to other corridors of country. In UP, state government has selected altogether 10 intervention districts for BBBP program on the basis of Child Sex Ratio. The Idea was on giving stress on the need of educating and protecting the girl child. BBBP is solely focused on the empowering of girl child. This has been creating waves throughout the state. This major inter-ministerial initiative taken up by the government of Uttar Pradesh, brings together ministries, institutions and also the civil societies, the program shall have a focused intervention and multi section action within 10 districts having low Child Sex ratio than average. BBBP addresses the declining Child Sex Ratio (CSR) and related issues of women empowerment over a life-cycle continuum. In Uttar Pradesh, state government has selected altogether 10 intervention districts (Baghpat, Gautam Buddha Nagar, Ghaziabad, Meerut, Bulandshahr, Agra, Muzaffarnagar, Mahamaya Nagar, Jhansi and Mathura) for BBBP program having low CSR than state average

\section{The objectives of this Program are:}

a. Prevention of gender biased sex selective elimination

b. Ensuring survival \& protection of the girl child

c. Ensuring education and participation of the girl child

Table 2: Districts Schools Indicators, U-DISE, 2017-18.

\begin{tabular}{|c|c|c|c|c|c|c|}
\hline District & $\begin{array}{l}\text { Number of } \\
\text { schools }\end{array}$ & $\begin{array}{c}\text { Enrolment } \\
\text { (Classes } 1 \text { to } 8 \text { ) }\end{array}$ & $\begin{array}{l}\text { Schools without } \\
\text { Female Teacher }\end{array}$ & $\begin{array}{c}\text { Schools not } \\
\text { having Girls Toilet }\end{array}$ & $\begin{array}{l}\% \text { of schools } \\
\text { having girls' toilet }\end{array}$ & $\begin{array}{l}\text { Pupil Teacher } \\
\text { Ratio (PTR) }\end{array}$ \\
\hline Baghpat & 1166 & 225810 & 709 & 0 & 99.66 & 37.34 \\
\hline $\begin{array}{c}\text { Gautam Buddha } \\
\text { Nagar }\end{array}$ & 1518 & 354983 & 177 & 5 & 99.47 & 38.8 \\
\hline Ghaziabad & 1720 & 484435 & 131 & 1 & 99.13 & 40.01 \\
\hline Meerut & 2880 & 516812 & 498 & 7 & 98.96 & 31.11 \\
\hline Bulandshahr & 4051 & 566047 & 1134 & 16 & 99.28 & 33.26 \\
\hline Agra & 4896 & 697852 & 1071 & 1 & 99.63 & 35.74 \\
\hline Muzaffarnagar & 2831 & 405045 & 678 & 6 & 99.47 & 26.97 \\
\hline Mahamaya Nagar & 2352 & 293452 & 633 & 0 & 99.83 & 27.14 \\
\hline
\end{tabular}

Cite this article: Vipul Vaibhav Pandey, Ajay Kumar Singh, Upadhaya SK. Beti Bachao Beti Padhao Program to Save the Girl Child-Educated the Girl Child: Impact Analysis of Government of India Flagship Program in Uttar Pradesh, India. Biomed J Sci\&Tech Res 10(4)-2018. BJSTR. 


\begin{tabular}{|c|c|c|c|c|c|c|}
\hline Jhansi & 2577 & 326477 & 541 & 7 & 97.48 & 23.86 \\
\hline Mathura & 3255 & 523477 & 1032 & 8 & 35.41 & 35.41 \\
\hline District & $\begin{array}{c}\text { Enrollment class } \\
1-5, \text { BOYS }\end{array}$ & $\begin{array}{c}\text { Enrollment class } \\
1-5, \text { Girls }\end{array}$ & \multicolumn{2}{|c|}{ Enrollment class 6-8, BOYS } & \multicolumn{2}{|c|}{ Enrollment class 6-8, Girls } \\
\hline Baghpat & 80493 & 68459 & \multicolumn{2}{|c|}{41579} & \multicolumn{2}{|c|}{35412} \\
\hline $\begin{array}{l}\text { Gautam Buddha } \\
\text { Nagar }\end{array}$ & 138614 & 120690 & \multicolumn{2}{|c|}{52223} & \multicolumn{2}{|c|}{52223} \\
\hline Ghaziabad & 177458 & 167062 & \multicolumn{2}{|c|}{70193} & \multicolumn{2}{|c|}{70001} \\
\hline Meerut & 189565 & 171707 & \multicolumn{2}{|c|}{80904} & \multicolumn{2}{|c|}{74636} \\
\hline Bulandshahr & 196768 & 193162 & \multicolumn{2}{|c|}{87947} & \multicolumn{2}{|c|}{88170} \\
\hline Agra & 257289 & 248894 & \multicolumn{2}{|c|}{96834} & \multicolumn{2}{|c|}{102249} \\
\hline Muzaffarnagar & 155244 & 136235 & \multicolumn{2}{|c|}{59306} & \multicolumn{2}{|c|}{54260} \\
\hline Mahamaya Nagar & 102284 & 99751 & \multicolumn{2}{|c|}{45955} & \multicolumn{2}{|c|}{45469} \\
\hline Jhansi & 114245 & 99762 & \multicolumn{2}{|c|}{59208} & \multicolumn{2}{|c|}{53262} \\
\hline Mathura & 200275 & 199402 & \multicolumn{2}{|c|}{63098} & \multicolumn{2}{|c|}{63857} \\
\hline District & $\begin{array}{l}\text { Girls repetition } \\
\text { rate } 1-5\end{array}$ & $\begin{array}{l}\text { Girls repetition } \\
\text { rate 6-8 }\end{array}$ & $\begin{array}{l}\text { Girls Promotion } \\
\quad \text { rate 1-5 }\end{array}$ & $\begin{array}{l}\text { Girls promotion } \\
\text { rate } 6-8\end{array}$ & $\begin{array}{l}\text { Girls Dropout } \\
\text { Rate 1-5 }\end{array}$ & $\begin{array}{c}\text { Girls Dropout rate } \\
6-8\end{array}$ \\
\hline Baghpat & 0.03 & 0.06 & 95.07 & 100 & 4.9 & 0 \\
\hline $\begin{array}{l}\text { Gautam Buddha } \\
\text { Nagar }\end{array}$ & 0.61 & 2.31 & 88.26 & 98.79 & 11.12 & 0 \\
\hline Ghaziabad & 0.02 & 0.02 & 98.65 & 98.57 & 1.33 & 1.41 \\
\hline Meerut & 0 & 0 & 90.58 & 100 & 9.42 & 0 \\
\hline Bulandshahr & 0.21 & 0.19 & 90.35 & 95.62 & 9.44 & 4.19 \\
\hline Agra & 0.07 & 0.03 & 88.07 & 100 & 11.87 & 0 \\
\hline Muzaffarnagar & 0 & 0.16 & 90.57 & 91.76 & 9.43 & 8.08 \\
\hline Mahamaya Nagar & 0.28 & 0.09 & 98.85 & 100 & 0.88 & 0 \\
\hline Jhansi & 0.05 & 0.32 & 90.79 & 87.63 & 9.16 & 12.05 \\
\hline Mathura & 0.61 & 0.9 & 89.58 & 100 & 9.82 & 0 \\
\hline
\end{tabular}

For the purpose of BBBP assessment UDISE data has been analyzed and outcomes of, FGDs, workshop's and activities encouraging the scheme were examine [1]. The program has a focused intervention and multi section action within these districts. The idea was on giving stress on the need of educating and protecting the girl child. In order to accomplish the objectives activities like, 10 district resource group has been formed, 102 Block level resource has been created [2]. Formation of Meena Munch, child cabinet. 21 convergence meetings has been done with ICDS department at block and school level. Along with it 608 Gender sensitization training and 3 Gender workshops has been conducted in partnership with SSA to sensitize teachers and stake holders. Around 20 Gender and health awareness program has been conducted at Gram Panchay at level. Also 2390 Girl child friendly school has been developed and 4650 disaster management training and mock drills conducted at school level where girls were trained to use help line number, women power line numbers (Table 2).

On the basis of above indicators, blocks were selected for community and school interventions. The focus group elucidate the issues of - what is the need to take this initiative by launching the drive Beti Bachao Beti Padhao? [3] It was emerges from the group discussion that, it is the responsibility of every human to save girl children. It must be ensured that they don't get killed in the womb of their mothers. After they are born, their quality education must be ensured. Participants from community responded that, if they can stand on their feet, the country will automatically stand. Few also mention about demand for severe punishment "Those who become the part of this great movement must be encouraged with rewards and those who don't mend their ways must be given exemplary punishment" (Table 3).

Cite this article: Vipul Vaibhav Pandey, Ajay Kumar Singh, Upadhaya SK. Beti Bachao Beti Padhao Program to Save the Girl Child-Educated the Girl Child: Impact Analysis of Government of India Flagship Program in Uttar Pradesh, India. Biomed J Sci\&Tech Res 10(4)-2018. BJSTR. MS.ID.001987. DOI: 10.26717/ BJSTR.2018.10.001987. 
Table 3: Program assessment shows that Following activities have been conducted in 10 selected districts under BBBP since its inception.

\begin{tabular}{|c|c|c|}
\hline S.N. & Activities & Physical progress \\
\hline 1 & $\begin{array}{l}\text { District resource group has been formed at district level. Orientation of DRG done by DC } \\
\text { girls. DRC is responsible for the effective implementation of BBBP in the district. They } \\
\text { conduct regular meeting to review the progress. }\end{array}$ & 10 groups \\
\hline 2 & $\begin{array}{l}\text { Block level resource has been formed at block level. Orientation of BRG done by DC } \\
\text { girls. BRG is headed by } 1 \text { nodal gender coordinator who is nominated by BEO. BRG is } \\
\text { responsible for the effective implementation of BBBP in the block. They conduct regular } \\
\text { meetings, organized motivational programmes etc and review the progress. }\end{array}$ & 102 \\
\hline 3 & $\begin{array}{l}\text { Meena manch has been formed at upper primary level in all schools to aware and } \\
\text { strengthen girls. Meena manch conducts regular meetings on the issues of equity. This } \\
\text { manch is a very effective platform for the discussion on gender related issues. }\end{array}$ & $\begin{array}{l}4650 \text { Manches has been formed and } 93160 \\
\text { girls are leading as founder member. }\end{array}$ \\
\hline 4 & $\begin{array}{l}\text { Child cabinet has been formed at primary level. Child cabinet supports children to develop } \\
\text { leader ship, participation, democratic process, decision making skills etc. }\end{array}$ & 10581 primary schools \\
\hline 5 & $\begin{array}{l}\text { Meeting with community- To aware community and Village level stake holder meeting } \\
\text { and parents conventions have been conducted regarding girls education. }\end{array}$ & $\begin{array}{l}321 \text { Village level meeting and } 23 \text { parents } \\
\text { conventions }\end{array}$ \\
\hline 9 & $\begin{array}{l}\text { Signature campaign and candle marches conducted at block and districts level. } \\
\text { Community pledged in favor of girl child. }\end{array}$ & $\begin{array}{l}\text { 5787-Signature campaign } \\
\text { 7- candle marches } \\
\text { 42229-person pledged }\end{array}$ \\
\hline 10 & Gender sensitization training has been conducted to sensitize teachers and stake holders. & 608 \\
\hline 14 & $\begin{array}{l}\text { To aware community on the theme of girl's education, rights, role of parents and stake } \\
\text { holders Nukkad Natak and theatre show organized at different level. }\end{array}$ & 6702 \\
\hline 15 & Nari Pakhwara celebrated on the vacation of girl's day for the mobilization of community. & 900 \\
\hline 16 & $\begin{array}{l}\text { Drop boxes had been set up in schools and girls are being promoted to drop their issues } \\
\text { and problems in the box. }\end{array}$ & 2150 \\
\hline 17 & $\begin{array}{l}\text { Good Touch Bad touch training given to girls at school level using video and other IEC } \\
\text { materials. }\end{array}$ & 99400 \\
\hline 18 & $\begin{array}{l}\text { Developed Girl child friendly school providing Safe environment, toilets, drinking water } \\
\text { and other required facilities. }\end{array}$ & 2390 \\
\hline 19 & $\begin{array}{l}\text { Disaster management training and mock drills conducted at school level with the } \\
\text { convergence of local NGOs, fire station, scout guide, police. Girls were trained to use help } \\
\text { line number, women power line numbers. }\end{array}$ & 4650 UPS covered \\
\hline
\end{tabular}

\section{What else needs to be done?}

The facts that need to noted is, only the allotment of funds shall not work, the laws need to be amended and made strict, vigorous punishment should be given to the culprits responsible for sex discrimination and sex selective abortions. The objectives of "Beti Bachao Beti Padhao" program needs to have a connection with the society at large which will make the citizens much more aware [4]. The campaigns have been boosting the morals of people and if you are looking for results, a dedicated effort is necessary clubbed with financial support. The collective views among the participants of the workshop was that, there are some associated problems in our society, for instance, people are more concerned about the marriage expenses, dowry, and discriminations in upbringing of a girl. These issues need to be eradicated so that individuals including parents become much more responsible regarding the duties in the upbringing of a girl. The issues need to be dealt in such a way that future parents are encouraged in a positive way. The moves like celebration on the birth of girl child, Schools and Community inspection visits, unregistered USG units sealing, oath taking ceremony, showing birth stats at the level of "Meena Munch" should be encouraged and practiced. Periodic surveys both at school and community are required for the impact evaluation of Beti Bacha Beti Padhao Program [5,6].

\section{References}

1. Angela Kohama (2012) Inclusive education in India: A country in transition.

2. Anne M Hocutt (1996) Effectiveness of special education: is placement the critical factor? Future Child 6(1): 77-102.

3. Balasundaram Pramila (2005) The Journey to words inclusive education in India. In Ben Schooley The effects of student attendance on student achievement.

4. Moredock H Stewart (1957) Measurement and evaluation in education.

5. Bumbalo J, Ustinich L, Ramcharran D, Schwalberg R (2005) Economic impact on families caring for children with special health care needs in new Hampshire: The effect of socioeconomic and health-related factors. Matern Child Health J 9(2): S3-S11.

6. Cleary PF, Pierce G, Trauth EM (2006) Closing the digital divide: Understanding racial, ethnic, social class, gender and geographic disparities in Internet use among school age children in the United States. Universal Access in the Information Society 4(4): 354-373. 
ISSN: 2574-1241

DOI: 10.26717/BJSTR.2018.10.001987

Vipul Vaibhav Pandey. Biomed J Sci \& Tech Res

(C) (P) This work is licensed under Creative

Submission Link: https://biomedres.us/submit-manuscript.php

$\begin{array}{ll}\text { BIOMEDICAL } & \text { Assets of Publishing with us } \\ \text { RESEARCHES } & \text { - Global archiving of articles } \\ \text { - Immediate, unrestricted online access } & \text { - Rigorous Peer Review Process } \\ & \text { - Authors Retain Copyrights }\end{array}$

